\title{
THE GEOGRAPHY OF TOURIST BEDNIGHTS IN SOUTH AFRICA
}

\author{
Jayne M. ROGERSON* \\ University of Johannesburg, School of Tourism \& Hospitality, College of Business \\ \& Economics, Bunting Road, Johannesburg (South Africa), e-mail: jayner@uj.ac.za
}

Citation: Rogerson, J.M. (2018). THE GEOGRAPHY OF TOURIST BEDNIGHTS IN SOUTH AFRICA. GeoJournal of Tourism and Geosites, 23(3), 835-847. https://doi.org/10.30892/gtg.23318-332

\begin{abstract}
The discipline of geography is a leading contributor to tourism research. Although tourism geography research covers a broad spectrum of issues and approaches the most distinctive approach that geography brings to tourism scholarship is through adopting a spatial view. Against the background of a review of international research using a spatial perspective on accommodation this paper analyses the geography of tourist bednights in South Africa. Bednights include commercial and noncommercial types of accommodation. The results show the majority of bednights in South Africa occur in non-commercial forms of accommodation because of the large volume of tourism in the country which is accounted by low-income VFR travellers most of whom do not use commercial accommodation services. Analysis of the spatial distribution of bednights discloses that the greatest share is represented in the country's largest metropolitan centres albeit important differences are observed in the balance between domestic and international bednights between the country's major cities. The patterns of domestic bednights are more spread than for international bednights. A highly distinctive feature of South Africa's geography of bednights is the particularly strong pattern of dominance of domestic bednights in the tourism economy of the mainly rural and former Homelands areas that were created under apartheid.
\end{abstract}

Key words: tourism, bednights, spatial approach, accommodation services, South Africa

\section{INTRODUCTION}

Scholarship in tourism studies has been enriched from many academic disciplines with geography one of its leading contributors (Butler, 2004). As expressed by Timothy (2018: 166) geographers were amongst "the very earliest of academics to ponder, theorize and examine the socio-spatial manifestations of tourism". With its strong spatial focus and synthesizing tradition across both physical and social sciences geography assumes a core status in tourism research (Visser, 2016). Che (2018) asserts that tourism geography occupies a 'central role' in understanding a globalized world. By way of example, the work of the geographer Richard Butler (1980) on the tourism area life cycle of evolution is seminal and arguably is the most cited individual article in global tourism research. It is

\footnotetext{
* Corresponding author
} 
contended that geography represents "the ideal discipline to study the global tourism industry given tourism's distinct place, time, distance and activity patterns which transform the economy and environment of visited places" (Che, 2018: 164). Timothy (2018) characterizes geography as "the substance of tourism". With geographers' varied interests in place, space and the environment they offer significant insights for the multidisciplinary terrain of tourism scholarship (Hall \& Page, 2006; Williams, 2009; Saarinen, 2014; Saarinen et al., 2017; Crouch, 2018; Gill, 2018; Ilies et al., 2016; 2017). Overall, it is stressed that the analytical toolkits of geographers are especially valued for interpreting regional patterns, tourism's impact on destinations, the industry's spatial growth, and flows of travellers from home to destinations (Timothy, 2018).

The outputs by Hall \& Page (2006, 2009), Hall (2013) and Müller (2018) all draw attention to an extended agenda and 'framing' of research by tourism geographers. This mirrors broader changes occurring within geography in which a descriptive tradition and mapping of the world is exchanged for more analytical approaches defining geography not as an object of study but instead as a perspective on society and the environment (Müller, 2018). Likewise, Timothy (2018: 166) comments that "the contributions of geography have far surpassed the normative perspectives that are commonly assumed to be the province of geography". This said, whilst the domain of tourism geography has a wide focus as is reflected in 20 years of publication of the journal Tourism Geographies it can be argued that the spatial viewpoint remains the most distinctive approach that geography brings to tourism research. The spatial viewpoint was one that was identified in Pearce's (1979) early review of geographical studies on tourism. Among several key focal themes for an emerging geography of tourism are analysis of the spatial aspects of demand and supply for tourism products. Some examples of the adoption of a spatial approach in tourism research include, inter alia, Forer \& Pearce (1984) study of package tourism in New Zealand, Pearce (1987) on the geographical organization of package tours in Europe, works by Pearce \& Grimmeau (1985) and by Barke \& France (1986) on the spatial structure of tourist accommodation supply and demand in Spain, Weaver \& Elliott (1996) on spatial issues and problems in Namibian tourism, Müller (2016) on geographical explanations of tourism success or failure in remote regions, Wang (2008) on the spatial structure of tourism resources in one Chinese region, Wen \& Sinha (2009) on the spatial patterns of tourism in China, Guedes \& Jiminez (2015) on the geographical patterns of cultural tourism in Portugal; and, Yang \& Wong (2013) on the spatial distribution of inbound and domestic tourism flows to China's cities.

From the foregoing it is apparent that in China, which is the fastest expanding region of the world in terms of publishing tourism scholarship (see Shen et al., 2018), there has been a strong take up of the spatial approach in tourism studies. South Africa also has witnessed the adoption and increasing application of the spatial approach in tourism studies. Geographers have studied the uneven development of the tourism space economy and identified issues about spatial imbalances in tourism (Visser, 2003, 2007; Rogerson, 2014, 2015a, 2015b, 2015d; Rogerson \& Nel, 2016; Rogerson, 2016a, 2016b; McKelly et al., 2017; Rogerson, 2017a, 2017b, 2017c, 2017d; Rogerson \& Rogerson, 2019). The relevance of the spatial approach in the context of sub-Saharan Africa was reiterated by Ahebwa \& Novelli (2014). These authors stress that an improved understanding of the spatial dimensions of tourism can result in better informed national and regional strategies for tourism development across sub-Saharan Africa. It is against this backcloth that in this paper a spatial approach is adopted to examine one particular dimension of the accommodation services sector in South Africa. The specific focus is upon analysing the geography of tourist bednights. Arguably, for destination managers data on tourism bednights can be one potentially useful index of tourism performance. The analysis draws upon official data on 
bednights from Statistics South Africa and from South African Tourism. In addition, it analyses bednight data contained in the IHS Global Insight data base which is a private sector data base that is widely utilised in local economic development planning in South Africa because of the paucity of official sub-national data. For tourism no municipal level data is available from official sources. For this investigation data is extracted from the IHS Global Insight data base for the period 2001 to 2015 on total tourism bednights, the spatial pattern of total bednights and of bednights as differentiated by origin of visit, whether domestic or international. The remainder of the discussion in this paper is organised in terms of two sections of discussion. As context, the next section provides a brief literature review of research surrounding tourism and accommodation services and in particular on spatial investigations. Attention then shifts to explore the macropicture of tourism bednights, the geography of tourism bednights and the differential patterns of bednights in respect of domestic as opposed to international tourism trips.

\section{TOURISM AND ACCOMMODATION SERVICES}

Although the largest volume of academic writings on accommodation services derives from the perspective of hospitality management there is an established stream of writings which examines aspects of accommodation services from a tourism perspective. In their influential volume Timothy \& Teye (2009) stress that the growth and consolidation of a commercial accommodation or lodging sector is an accompaniment as well as facilitator for tourism development in any country. Ritchie \& Crouch (2003) identify the development of accommodation facilities as the basis for the growth of any tourist destination and stress that their absence "acts as a constraint on overnight visitor numbers". Accordingly, Navratil et al. (2012: 50) can assert that strengthening of "the accommodation capacities is one of the essential parts of the process of planning tourism development in destinations". For Romania Rahovan (2013) affirms the critical role of hotel accommodation services for tourism development. Overall, across the international record the availability of an array of accommodation services is shown to be an indispensable element of the infrastructure for competitiveness' for any tourism destination. This is especially so in emerging tourism regions such as contemporary Africa (Christie et al., 2013; Rogerson \& Rogerson, 2018).

Within the context of sub-Saharan Africa an undersupply or poor quality of adequate accommodation services (particularly hotels) is identified by World Bank researchers as one of the key blockages on tourism development for several countries (Ernst \& Young, 2011). Across sub-Saharan Africa the competitiveness of countries as tourism destinations is conditional upon establishing a network of different forms of accommodation at competitive prices and of acceptable quality standards (Rogerson \& Rogerson, 2018). One good illustration is provided by Malawi where, as a result of inadequate provision of accommodation services, tourism in the country was undeveloped (Magombo et al., 2017). By contrast, South Africa provides a 'good practice' case study in the restructuring and upgrading of accommodation services sector following democratic transition and the country's post-1994 re-entry into the international tourism economy (Rogerson, 2013a, $2013 \mathrm{~b})$. As a consequence of the diversification of accommodation services, tourists in South Africa enjoy an array of accommodation offerings including luxury hotels and safari lodges, boutique hotels, limited service and all-suite hotels, guest houses, bed and breakfasts, self-serviced apartments, backpacker hostels, camp sites and, most recently, Airbnb home stays (Rogerson, 2010, 2011a, 2011b, 2013c, 2013d; Rogerson \& Rogerson, 2014; Greenberg \& Rogerson, 2015; Visser et al., 2017; Rogerson \& Rogerson, 2019).

In international research on accommodation services and tourism there is a vibrant literature that has emerged out of adopting a spatial view. Not surprisingly, the largest amount of writings relate to hotels. Since 2000 a considerable amount of work has 
examined various issues around hotel location at different scales of analysis, global, national, regional and intra-urban. Key theoretical contributions have appeared in the writings of Egan \& Nield (2000) and by Yang et al. (2014). The globalization of hotel chains and their location patterns has galvanized the growth of several theoretical and empirical contributions (Ivanova, 2013; Boyen \& Ogasavara, 2013; Ivanova \& Ivanov, 2014; Niewiadomski, 2014; Niewiadomski, 2015; Ivanova et al., 2016; Niewiadomski, 2016; Niñerola et al., 2016; Rogerson, 2016; Santos et al., 2016). At the national scale of study the spatial pattern of hotel distribution in China (Luo \& Yang, 2013), the geographical clustering of hotels in Switzerland (Lund, 2006), the diffusion and spread of tourism accommodation in Spain (Pons et al., 2014), tourism enterprises' location decisions in Greece (Polyzos \& Minetos, 2011), the locational influences on foreign and domestic hotel investors (Puciato et al., 2017), and the relationship between the distribution of hotels and amenities in the USA (Lee et al., 2018) are some examples of recent research allied to a spatial perspective. The attractiveness of localities for investment is another critical theme that has secured scholarly attention (Puciato, 2016). The intra-urban scale of hotel location, however, has generated the greatest amount of interest (Bégin, 2000; Shoval \& CohenHattab, 2001; Urtasun \& Gutiérrez, 2006; Shoval, 2006; Shoval et al., 2011; Rogerson, 2012; Yang et al., 2012; Adam, 2013: Adam \& Amuquandoh, 2014; Rogerson, 2014a, 2014b). An historical lens is applied to analyse spatial-temporal variations in hotel development in Manhattan, New York from 1822 to 2012 (Li \& Du, 2018). In a contemporary investigation Luo \& Yang (2016) offer an analysis of the role of agglomeration economies in determining hotel location choices in Beijing. In recent research on Lisbon a comparison is undertaken of the locational influences on the hotels and budget hostels in the city (Cro \& Martins, 2018).

Outside of the hotel sector a number of other researchers have utilised a spatial view to interpret the evolving organisation of various types of lodging services. An important study is that of Walford (2011) who interrogates the spatial distribution of farm-based tourist accommodation in England and Wales. In contemporary research publications a trend is observable that the growth of peer-to-peer accommodation is garnering the most attention. Important works have appeared to unpack the spatial imprint of Airbnb in cities such as Barcelona (Gutierrez et al., 2017), Budapest (Boros et al., 2018), Cape Town (Visser et al., 2017) and Paris (Heo et al., 2019). Other studies have shifted to examine tourism gentrification in cities highlighting issues in residential gentrified areas as a result (in part) of the major expansion of shared economy accommodation (Gurran \& Phibbs, 2017). In a useful comparative study undertaken in the Czech Republic Navratil et al. (2012) examine whether differences are observed in the spatial characteristics of particular types of accommodation facilities. In terms of hotels, guest houses, and hostels it was revealed that the location of individual types of accommodation facilities does differ significantly between different forms of accommodation services. Certainly, this conclusion is supported by the findings from a range of recent South African studies which probe the location and character of different segments of commercial accommodation services. It is evidenced from South African research that different types of accommodation reveal a different geographical footprint (Rogerson \& Rogerson, 2019). Sharp differences are discernible in the spatial patterns as revealed in studies of guest houses, nature-based accommodation, time-share resorts, boutique hotels, second homes, backpacker hostels, Airbnb home stays as well as different types of hotels (Visser \& Van Huyssteen, 1997, 1999; Rogerson, 2010, 2011a, 2011b; Pandy \& Rogerson, 2013a, 2013b; Hay \& Visser, 2014; Pandy \& Rogerson, 2014a, 2014b; Rogerson \& Rogerson, 2014; Greenberg \& Rogerson, 2015; Hay \& Hay, 2017; Visser et al., 2017). Beyond these different segments of commercial accommodation, there is a radically different geography of non-commercial accommodation services. This segment of non-commercial accommodation centres around the supply of home-based accommodation 
to cohorts of (mainly) domestic low-income VFR travellers (Rogerson, 2017c, 2017d). In terms of the spatial structure of non-commercial accommodation, it includes destinations throughout South Africa, however, the relative importance of the former Homelands areas is noted as highly significant and distinctive (Rogerson, 2015b; 2017c).

\section{TOURISM BEDNIGHTS IN SOUTH AFRICA}

Estimates of the national picture regarding total bednights for South Africa are available in data sets provided by South African Tourism (2016) and Statistics South Africa (2015). In seeking to understand the spatial distribution of bednights, however, one must turn to analyse the IHS Global Insight data base. For 2016 the official estimates are that total bednights in South Africa were in the order of 192.2 million of which 103.4 million was accounted for by domestic tourism as compared to a total of 88.8 million by international visitors (including regional African tourists) (South African Tourism, 2016: 8). Of these totals of bednights, the data presented by South African Tourism indicates that only 17 percent of bednights were recorded for holiday purposes, 10 percent for business and 4.3 percent for other purposes, mainly for religion or medical tourism. The South African Tourism data show that overwhelmingly the largest share of bednights is accounted for by the category of Visiting, Friends and Relatives. It is indicated that of South Africa's national total of bednights in 2016 as much as 68.7 percent is represented by VFR tourism; of the category of domestic tourists it is revealed that as much as 74.3 percent of estimated bednights is accounted for by VFR travellers. The critical significance of this finding is that whilst a small segment of South African VFR tourists do use commercial accommodation services the vast majority of VFR is low-income (mainly Black) tourists who stay outside of commercial accommodation (Rogerson, 2017c, 2017d). Further data concerning accommodation usage by Statistics Africa for 2015 on domestic tourism indicates that as much as 70 percent of all trips in South Africa are taken in noncommercial accommodation (Statistics South Africa, 2015: 26).

What these national findings confirm is that in terms of total bednights the largest segment is recorded in non-commercial forms of accommodation because of the substantial weight of VFR travellers. The national picture of tourism bednights in South Africa is thus massively influenced by the overall patterns of VFR travel (Rogerson, 2015b). Indeed, as indexed by numbers of bednights, this finding points to the fact that the category of private homes is far more significant than either hotels, guest houses or bed and breakfasts in terms of the overall supply of accommodation services. Attention shifts now to examine the spatial distribution of bednights (Figure 1). Table 1 provides an analysis of the relative share of South Africa's leading centres as indexed by total bednights in 2001 and 2015. In terms of the geography of bednights in South Africa the national picture is dominated consistently by the country's leading metropolitan centres. In 2001 the eight metropolitan centres of Buffalo City, Cape Town, Ekurhuleni, eThekwini, Johannesburg, Mangaung, Nelson Mandela Bay and Tshwane accounted for 41.3 percent of national bednights. By 2015 the share of these eight centres had grown to 44.6 percent indicating a growing extent of spatial concentration. Outside of the metropolitan centres the two secondary cities of Polokwane and Mbombela are also leading national foci in terms of bednights. In looking at the differential performance of the ten leading centres it is noted that over the period 20012015 there occurs the relative strengthening of Cape Town, eThekwini, Tshwane, Polokwane, Mbombela, Mangaung and Buffalo City. In absolute terms, however, the rank order of destinations in terms of total bednights is unchanged with the dominance of Johannesburg followed by Cape Town, eThekwini, Tshwane and Ekurhuleni.

Table 2 provides a profile of the leading destinations as indexed by total domestic bednights for 2001-2015. In total the eight metropolitan centres accounted for 35.2 million or 37.7 percent domestic bednights in 2001. 


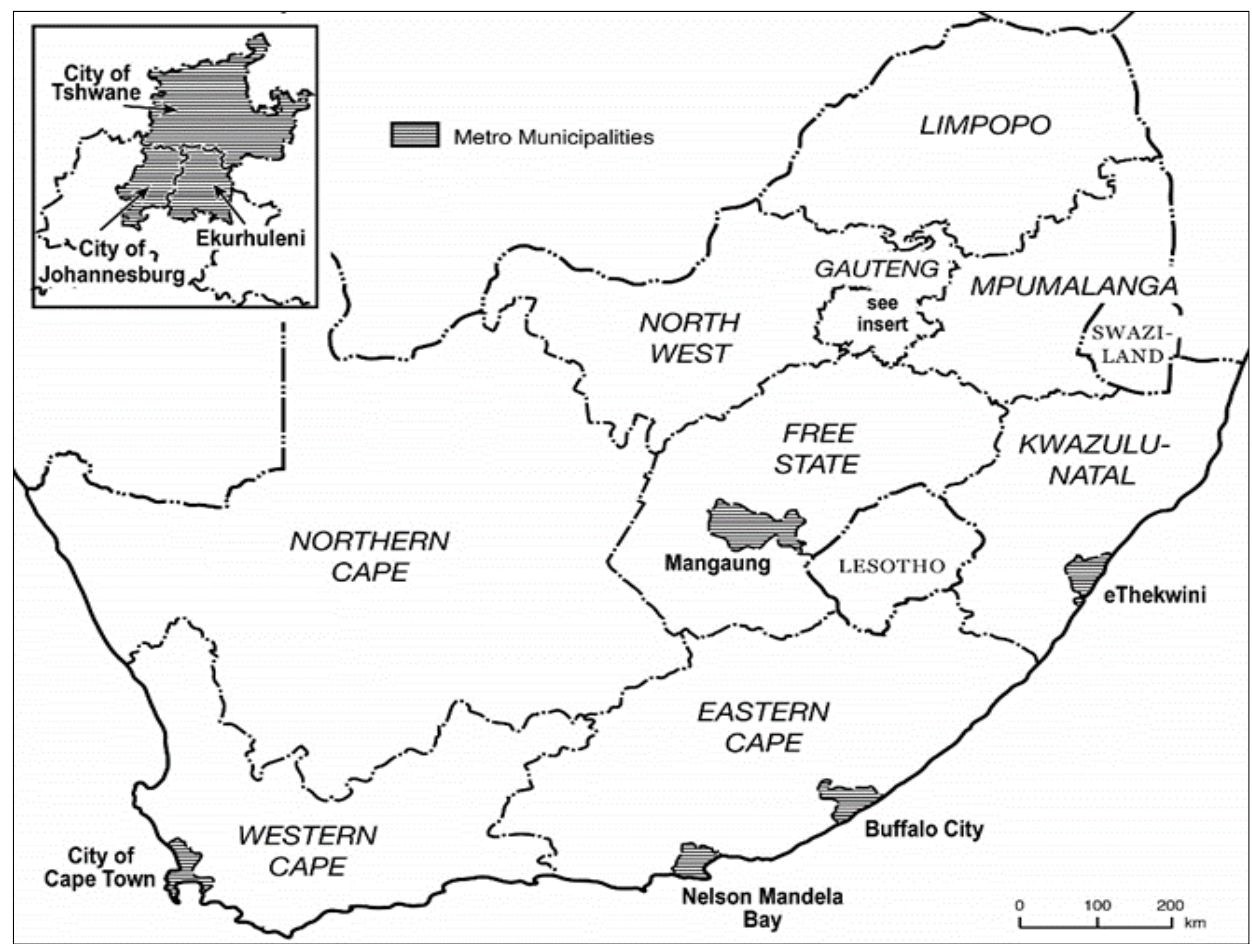

Figure 1. Location Map of South African Provinces and Major Metropolitan Centres

Table 1. Total Bednights: Leading Municipalities 2001-2015 (Data source: IHS Global Insight date)

\begin{tabular}{|c|c|c|c|c|c|}
\hline Municipality & $\begin{array}{c}\text { Settlement } \\
\text { Type }\end{array}$ & $\begin{array}{c}2001 \\
\text { Share (\%) } \\
\end{array}$ & \begin{tabular}{|c|} 
Total Bednights \\
2001 \\
\end{tabular} & \begin{tabular}{|c|}
2015 \\
Share (\%) \\
\end{tabular} & \begin{tabular}{|c|} 
Total Bednights \\
2015 \\
\end{tabular} \\
\hline Johannesburg & Metropolitan & 9.7 & 12494319 & 9.5 & 16224055 \\
\hline Cape Town & Metropolitan & 7.6 & 9810921 & 8.1 & 13852724 \\
\hline eThekwini & Metropolitan & 7.3 & 9431579 & 7.8 & 13365580 \\
\hline Tshwane & Metropolitan & 6.1 & 7827498 & 6.3 & 10754400 \\
\hline Ekurhuleni & Metropolitan & 4.9 & 6377317 & 4.9 & 8381711 \\
\hline Polokwane & Secondary City & 1.3 & 1699644 & 2.5 & 4246218 \\
\hline Mangaung & Metropolitan & 2.1 & 2762400 & 2.3 & 3954844 \\
\hline Mbombela & Secondary City & 1.6 & 2122240 & 2.3 & 3947834 \\
\hline Buffalo City & Metropolitan & 1.1 & 1378842 & 1.9 & 3263610 \\
\hline Nelson Mandela Bay & Metropolitan & 2.5 & 3277390 & 1.8 & 3003091 \\
\hline
\end{tabular}

By 2015 the numbers of domestic bednights as a whole had expanded in metropolitan centres to 39.2 million but the relative share of the national total had been reduced to 36.9 percent. This suggests that non-metropolitan centres, such as secondary cities, small towns and rural areas, are taking up an increasing proportion of domestic bednights. The rise in significance of the two leading secondary cities - Polokwane and Mbombela - in terms of absolute growth and relative share of domestic bednights is evidenced on Table 2. Overall, in terms of domestic bednights by 2015 eThekwini was the leading individual destination in South Africa having surpassed Johannesburg which was the most significant destination in 2001. This change is accounted for, in part, by a restructuring of metropolitan boundaries which resulted in the incorporation into the eThekwini extended metropolitan area of substantial tracts of 'rural spaces' which are major zones for VFR travel. In addition, as a 
whole, over recent years it has been shown there has been a recorded strengthening in the relative position of eThekwini as a domestic tourism destination (Rogerson, 2015a).

Table 2. Total Domestic Bednights: Leading Municipalities 2001-2015 (Data source: IHS Global Insight data)

\begin{tabular}{|l|c|c|c|c|c|}
\hline \multicolumn{1}{|c|}{ Municipality } & $\begin{array}{c}\text { Settlement } \\
\text { Type }\end{array}$ & $\begin{array}{c}\text { 2001 } \\
\text { Share (\%) }\end{array}$ & $\begin{array}{c}\text { Total Bednights } \\
\text { 2001 }\end{array}$ & $\begin{array}{c}\text { 2015 } \\
\text { Share (\%) }\end{array}$ & $\begin{array}{c}\text { Total Bednights } \\
\text { 2015 }\end{array}$ \\
\hline eThekwini & Metropolitan & 8.0 & 7478573 & 10.5 & 11182250 \\
\hline Johannesburg & Metropolitan & 8.2 & 7683756 & 6.2 & 6644309 \\
\hline Cape Town & Metropolitan & 5.9 & 5528347 & 5.9 & 6277310 \\
\hline Tshwane & Metropolitan & 5.1 & 4764480 & 4.6 & 4951339 \\
\hline Polokwane & Secondary City & 1.6 & 1546831 & 3.6 & 3860370 \\
\hline Ekurhuleni & Metropolitan & 4.2 & 3906623 & 3.1 & 3329054 \\
\hline Buffalo City & Metropolitan & 1.2 & 1099433 & 2.8 & 2954497 \\
\hline Nelson Mandela Bay & Metropolitan & 3.0 & 2750757 & 2.4 & 2399204 \\
\hline Mbombela & Secondary City & 1.3 & 1240958 & 2.1 & 2219242 \\
\hline Mangaung & Metropolitan & 2.1 & 1993016 & 1.4 & 1467116 \\
\hline
\end{tabular}

Table 3. Total International Bednights: Leading Municipalities 2001-2015(Data source: IHS Global Insight data)

\begin{tabular}{|l|c|c|c|c|c|}
\hline Municipality & Settlement Type & $\begin{array}{c}\text { 2001 } \\
\text { Share (\%) }\end{array}$ & $\begin{array}{c}\text { Total Bednights } \\
\text { 2001 }\end{array}$ & $\begin{array}{c}\text { 2015 } \\
\text { Share (\%) }\end{array}$ & $\begin{array}{c}\text { Total Bednights } \\
\text { 2015 }\end{array}$ \\
\hline Johannesburg & Metropolitan & 13.4 & 4810562 & 14.9 & 9579746 \\
\hline Cape Town & Metropolitan & 11.9 & 4282575 & 11.8 & 7575415 \\
\hline Tshwane & Metropolitan & 8.5 & 3063018 & 9.0 & 5803061 \\
\hline Ekurhuleni & Metropolitan & 6.9 & 2470694 & 7.8 & 5052657 \\
\hline Mangaung & Metropolitan & 2.1 & 769384 & 3.9 & 2487728 \\
\hline eThekwini & Metropolitan & 5.4 & 1953006 & 3.3 & 2183329 \\
\hline Mbombela & Secondary City & 2.4 & 881282 & 2.7 & 1728592 \\
\hline Matjhabeng & Secondary City & 0.6 & 228234 & 1.6 & 1031812 \\
\hline Mogale City & Secondary City & 1.7 & 616451 & 1.5 & 959590 \\
\hline Nkomazi & Small Town/Rural Area & 1.0 & 337520 & 1.4 & 915938 \\
\hline
\end{tabular}

On Table 3 is represented the unpacking of bednight data for international visitors. At the outset in terms of interpreting Table 3 it must be understood that the numbers of international bednights is substantially influenced by the significance of regional African visitors who represent almost 80 percent of all South Africa's cohort of international tourists (Rogerson, 2017a). It is evident that the distribution of international bednights is far more concentrated than for domestic bednights. Metropolitan dominance is reflected once again in the fact that the leading six metropolitan centres account for 48.2 percent of all international bednights in 2001 and as much as 50. 7 percent by 2015. The total international bednights in these six leading metropolitan destinations - Johannesburg, Cape Town, Tshwane, Ekurhuleni, Mangaung and eThekwini - expands by more than double from 14.6 million in 2001 to 30.5 million bednights by 2015. For international bednights the three Gauteng metropolitan areas of Johannesburg, Tshwane and Ekurhuleni - emerge strongly because of the high flows of regional African visitors many of them informal business travellers engaged in cross-border shopping (Rogerson, 2018). The city of Cape Town, however, records the second largest numbers of international bednights as South Africa's most iconic destination for long haul international tourists from Europe, North America, Asia or Australasia. Beyond the leading six metropolitan centres one observes for international bednights the significance of Mbombela, the gateway to Kruger National Park, Matjhabeng which receives large numbers of visitors from Lesotho, Mogale City in Gauteng a focal point for attracting regional African visitors, and Nkomazi which is a local municipality that is a borderland for both Swaziland and Mozambique and thus 
receives substantial flows of cross-border visitors. Overall, as compared to the patterns of domestic bednights one observes in respect of the metropolitan centres the reduced importance of the three coastal cities of eThekwini, Buffalo City and Nelson Mandela Bay.

Table 4. South Africa's Metropolitan Municipalities (2011 boundaries): Locational Quotients for Domestic and International Bednights, 2001 and 2015 (Data source: IHS Global Insight data)

\begin{tabular}{|l|c|c|c|c|}
\hline & Domestic 2001 & Domestic 2015 & International 2001 & International 2015 \\
\hline Cape Town & 0.78 & 0.72 & 1.49 & 1.22 \\
\hline eThekwini & 1.09 & 1.34 & 0.63 & 0.37 \\
\hline Ekurhuleni & 0.84 & 0.63 & 1.68 & 1.80 \\
\hline Johannesburg & 0.85 & 0.65 & 1.68 & 1.78 \\
\hline Nelson Mandela Bay & 1.16 & 1.28 & 0.55 & 0.55 \\
\hline Tshwane & 0.84 & 0.73 & 1.73 & 1.62 \\
\hline Mangaung & 0.99 & 0.59 & 1.02 & 1.66 \\
\hline Buffalo City & 1.10 & 1.45 & 0.71 & 0.25 \\
\hline
\end{tabular}

Finally, in terms of examining tourism bednights in South Africa as differentiated by international and domestic origin Tables 4 and 5 present the calculation of location quotients for respectively the eight metropolitan areas (Table 4) and for outside the metropolitan areas in South Africa's 44 District Municipalities. Using the available bednight information these location quotients for 2001 and 2015 provide an index of the relative importance of areas for domestic as opposed to international visitors. An index score of $>1.0$ signifies a relative concentration as compared to the national profile; a location quotient score of $<1.0$ correspondingly is indicative of the fact that particular types of visitors are relatively under-represented as compared to the national total. Several key points emerge from Tables 4 and 5. First, in terms of the metropolitan areas, the analysis highlights the differential importance of domestic as opposed to international tourism in different metropolitan centres. The location quotients reveal evidence that Cape Town, Johannesburg, Ekurhuleni, Tshwane and Mangaung are relatively 'over-represented' and thus concentrated in terms of international bednights. By contrast, the three coastal centres of eThekwini, Nelson Mandela Bay and Buffalo City emerge as dominant for domestic bednights. Second, in terms of the analysis of the district municipalities an uneven geographical pattern emerges. In terms of international tourism the districts that emerge as 'over-represented' are clustered in particular regions of South Africa. It is evident that all the districts in Western Cape, which is popular for long haul tourists, exhibit the relative dominance for international tourism and corresponding relative weakness for domestic tourism. Likewise, the cluster of district municipalities which are borderlands exhibit high scores for international tourism, albeit in the cases of Free State, Limpopo and Kwa-Zulu Natal this is on the basis of regional visitors from Lesotho, Swaziland, Zimbabwe or Mozambique rather than longhaul from Europe, North America or Asia.

Three, the sparsely settled and remote areas of the Northern Cape province record high scores which reflect the relative strength of domestic tourism and the minimal growth of international tourism. This said, the group of district municipalities which record the highest location quotient scores for domestic tourism correspond closely to the areas delimited and defined under apartheid as the former Homelands. These areas are major areas for outmigration, translocal households and for the occurrence of VFR travel (Rogerson, 2017c). Overall, the character of the tourism economy in most of these areas is of the overwhelming dominance of domestic VFR travellers and most importantly of a non-commercial accommodation sector. In the former Homelands areas the commercial accommodation services sector - in terms of hotels, bed and breakfasts or guest houses - is sparse because of the limited market demand from (almost exclusively Black) low income VFR travellers. 
The Geography of Tourist Bednights in South Africa

Table 5. South Africa's District Municipalities: Location Quotients for Domestic and International Bednights, 2001 and 2015 (Data source: IHS Global Insight data)

\begin{tabular}{|c|c|c|c|c|c|}
\hline Province & District Municipality & \begin{tabular}{|c|} 
Domestic \\
2001 \\
\end{tabular} & \begin{tabular}{|c|} 
Domestic \\
2015 \\
\end{tabular} & \begin{tabular}{|c|} 
International \\
2001 \\
\end{tabular} & $\begin{array}{c}\text { International } \\
2015 \\
\end{array}$ \\
\hline Western Cape & West Coast & 0.88 & 0.88 & 1.29 & 1.19 \\
\hline Western Cape & Cape Winelands & 0.85 & 0.71 & 1.37 & 1.47 \\
\hline Western Cape & Overberg & 0.95 & 0.86 & 1.10 & 1.22 \\
\hline Western Cape & Eden & 0.79 & 0.57 & 1.52 & 1.69 \\
\hline Western Cape & Central Karoo & 0.99 & 0.80 & 1.01 & 1.32 \\
\hline Eastern Cape & Cacadu & 0.96 & 1.22 & 1.08 & 0.62 \\
\hline Eastern Cape & Amatole & 1.15 & 1.37 & 0.59 & 0.37 \\
\hline Eastern Cape & Chris Hani & 1.29 & 1.45 & 0.23 & 0.24 \\
\hline Eastern Cape & Joe Gqabi & 1.01 & 1.32 & 0.98 & 0.46 \\
\hline Eastern Cape & O.R. Tambo & 1.29 & 1.45 & 0.24 & 0.25 \\
\hline Eastern Cape & Alfred Nzo & 1.31 & 1.48 & 0.19 & 0.20 \\
\hline Northern Cape & Namakwa & 1.06 & 1.23 & 0.82 & 0.60 \\
\hline Northern Cape & Pixley ka Seme & 1.13 & 1.16 & 0.64 & 0.73 \\
\hline Northern Cape & ZF Mgcawu & 1.14 & 1.25 & 0.63 & 0.58 \\
\hline Northern Cape & Francis Baard & 1.01 & 1.33 & 0.97 & 0.45 \\
\hline Northern Cape & John TaoloGaetsewe & 1.16 & 1.45 & 0.58 & 0.25 \\
\hline Free State & Xhariep & 0.90 & 0.67 & 1.24 & 1.54 \\
\hline Free State & Lejweleputswa & 1.10 & 0.61 & 0.71 & 1.64 \\
\hline Free State & Thabo Mofutsanyane & 0.80 & 0.60 & 1.50 & 1.64 \\
\hline Free State & Fezile Dabi & 1.08 & 0.71 & 0.76 & 1.46 \\
\hline KwaZulu-Natal & Ugu & 1.05 & 1.26 & 0.85 & 0.56 \\
\hline KwaZulu-Natal & uMgungundlovu & 1.16 & 1.32 & 0.58 & 0.45 \\
\hline KwaZulu-Natal & Uthukela & 1.18 & 1.29 & 0.51 & 0.50 \\
\hline KwaZulu-Natal & Umzinyathi & 1.10 & 1.32 & 0.74 & 0.45 \\
\hline KwaZulu-Natal & Amajuba & 1.15 & 1.42 & 0.59 & 0.30 \\
\hline KwaZulu-Natal & Zululand & 1.20 & 1.38 & 0.46 & 0.36 \\
\hline KwaZulu-Natal & Umkhanyakude & 0.97 & 1.13 & 1.05 & 0.77 \\
\hline KwaZulu-Natal & Uthungulu & 1.06 & 1.28 & 0.84 & 0.53 \\
\hline KwaZulu-Natal & iLembe & 1.14 & 1.28 & 0.63 & 0.52 \\
\hline KwaZulu-Natal & Sisonke & 1.03 & 1.38 & 0.92 & 0.36 \\
\hline North-West & Bojanala & 0.92 & 1.04 & 1.18 & 0.93 \\
\hline North-West & Ngaka Modiri Molema & 1.26 & 1.26 & 0.31 & 0.55 \\
\hline North-West & Dr Ruth Segomotsi Mompati & 1.28 & 1.38 & 0.27 & 0.36 \\
\hline North-West & Dr Kenneth Kaunda & 0.96 & 1.12 & 1.10 & 0.78 \\
\hline Gauteng & Sedibeng & 1.01 & 0.56 & 0.97 & 1.72 \\
\hline Gauteng & West Rand & 0.76 & 0.59 & 1.61 & 1.67 \\
\hline Mpumalanga & Gert Sibande & 0.95 & 1.13 & 1.12 & 0.78 \\
\hline Mpumalanga & Nkangala & 0.92 & 1.02 & 1.19 & 0.95 \\
\hline Mpumalanga & Ehlanzeni & 0.92 & 0.84 & 1.20 & 1.25 \\
\hline Limpopo & Mopani & 1.22 & 1.27 & 0.42 & 0.54 \\
\hline Limpopo & Vhembe & 1.14 & 1.18 & 0.61 & 0.68 \\
\hline Limpopo & Capricorn & 1.29 & 1.44 & 0.22 & 0.25 \\
\hline Limpopo & Waterberg & 1.04 & 1.18 & 0.88 & 0.68 \\
\hline Limpopo & Greater Sekhukhune & 1.22 & 1.41 & 0.41 & 0.31 \\
\hline
\end{tabular}

\section{CONCLUSIONS}

Destination planning at any scale of analysis - national, regional or local - can be improved by a better understanding of the spatially differentiated character of the tourism economy. In this paper an analysis was done of tourist bednights which 
includes both commercial and non-commercial accommodation services. Under examination was the geographical patterns of bednights across South Africa. It was shown that in the South African case the national data points to the fact that the majority of bednights are in non-commercial forms of accommodation because of the large volume of tourism accounted by low-income VFR travellers most of whom do not use commercial accommodation services. The spatial distribution of bednights shows that the greatest share is accounted for in the country's largest metropolitan centres but that notable differences emerge in the balance between domestic and international bednights between the country's major cities. The patterns of domestic bednights are more spread than the concentrations revealed for international bednights. A highly distinctive feature of the geography of bednights in South Africa is the particularly strong pattern of dominance of domestic bednights in the tourism economy of the mainly rural former Homelands areas that were created under apartheid.

This is explained by the limited tourism economies of these areas which are massively weighted towards VFR travellers. These findings can inform local destination planning for tourism in South Africa as they provide a set of baseline information about the character of local tourism economies. Strategic tourism planning must triangulate these results about bednights with other fine-grained research about purpose of travel as well as information on local tourism spend patterns in destinations.

\section{Aknowlegments}

Thanks to Jonathan Rogerson for data analysis and to Teddy, Skye and Dawn Norfolk for useful inputs.

\section{REFERENCES}

Adam, I. (2013). Urban Hotel Development Patterns in the Kumasi Metropolis, Ghana. Tourism Planning \& Development, vol. 10, no. 1, p. 85-98.

Adam, I., \& Amuquandoh, F.E. (2014). Hotel Characteristics and Location Decisions in Kumasi Metropolis, Ghana. Tourism Geographies, vol. 16, no. 4, p. 653-668.

Ahebwa, W.M., \& Novelli, M. (2014). African Tourism and Hospitality in Global Society: Central or Peripheral? Tourism and Hospitality Research, vol. 14, nos. 1-2, p. 3-7.

Barke, M., \& France, L. (1986). Tourist accommodation in Spain 1971-1981. Tourism Management, vol.7, no. 3,p.181-196.

Bégin, S. (2000). The Geography of a Tourist Business: Hotel Distribution and Urban Development in Xiamen, China. Tourism Geographies, vol. 2, p. 448-471.

Boros, L., Dudas, G., Kovalcsik, T., Papp, S., \& Vida, G. (2018). Airbnb in Budapest: Analysing Spatial Patterns and Room rates of Hotels and Peer-to-Peer Accommodation. GeoJournal of Tourism and Geosites, vol. 21, no.1,p. 26-38.

Boyen, M.H., \& Ogasavara, M.H. (2013). Internationalization patterns of multinational lodging firms in Brazil. Tourism and Hospitality Research, vol. 13 no. 4, p. 181-20o.

Butler, R., (1980). The Concept of a Tourist Area Cycle of Evolution: Implications for Management of Resources. Canadian Geographer, vol. 24, no. 1, p. 5-12.

Butler, R. (2004). Geographical Research on Tourism, Recreation and Leisure: Origins, Eras, and Directions. Tourism Geographies, vol. 6, no. 2, p. 143-162.

Che, D. (2018). Tourism Geography and its Central Role in a Globalized World. Tourism Geographies, vol.20.no. 1,p.164-165.

Christie, I., Fernandes, E., Masserli, H., \& Twining-Ward, L. (2013). Tourism in Africa: Harnessing Tourism for Growth and Improved Livlihoods. Washington D.C.: The World Bank.

Cro, S., \& Martins, A.M. (2018). Hotel and Hostel Location in Lisbon: Looking for Their Determinants. Tourism Geographies, vol. 20, no. 3, p. 504-523.

Crouch, D. (2018). Changing Geographies and Tourist Scholarship. Tourism Geographies, vol. 20, no. 1, p. $175-177$.

Egan, D. J., \& Nield, K. (2000). Towards a Theory of Intraurban Hotel Location. Urban Studies, vol. 37, p. $611-621$.

Ernst \& Young (2011). Sub-Saharan Africa Hospitality Overview. Report prepared for the World Bank, Washington DC.

Forer, P.C., \& Pearce, D.G. (1984). Spatial Patterns of Package Tourism in New Zealand. New Zealand Geographer, vol. 40, no. 1, p. 34-43.

Gill, A. (2018). Reflections on Institutional and Paradigmatic Changes in Tourism Geography: A Canadian Perspective. Tourism Geographies, vol. 20, no. 1, p. 185-186. 
Greenberg, D., \& Rogerson, J.M. (2015). The Serviced Apartment Industry of South Africa: A New Phenomenon in Urban Tourism. Urban Forum, vol. 26 no. 4, p. 467-482.

Guedes, A.S., \& Jiminez, M.I.M. (2015). Spatial Patterns of Cultural Tourism in Portugal. Tourism Management Perspectives, vol. 16, p. 107-115.

Gurran, N., \& Phibbs, P. (2017). When Tourists Move in: How Should Urban Planners Respond to Airbnb. Journal of the American Planning Association, vol. 83, no. 1, p. 80-92.

Gutierrez, J., Garcia-Palomares, J.C., Romaillos, G., \& Salas-Olmedio, M.H. (2017). The Eruption of Airbnb in Cities: Comparing Spatial Patterns of Hotels and Peer-to-peer Accommodation in Barcelona. Tourism Management, vol. 62, p. 278-291.

Hall, C.M.(2013). Framing Tourism Geography: Notes from the Underground. Annals of Tourism Research, vol.43,p.601-623.

Hall, C.M., \& Page, S.J. (2006). The Geography of Tourism and Recreation: Environment, Place and Space. London: Routledge.

Hall, C.M., \& Page, S.J. (2009). Progress in Tourism Management: From the Geography of Tourism to Geographies of Tourism - A Review. Tourism Management, vol. 30, p. 3-16.

Hay, A., \& Hay, J. (2017). Indicators of Post-productivism in South Africa's 'Platteland': A Second Home Case Study of Rosendal, Eastern Free State. Bulletin of Geography: Socio-Economic Series, vol. 37, p. 35-49.

Hay, E.A., \& Visser, G. (2014). The Socio-cultural and Socio-economic Features of Second Homes in Rosendal, South Africa. Bulletin of Geography: Socio-Economic Series, vol. 26, p. 157-166.

Heo, C.Y., Blal, I., \& Choi, M. (2019). What is Happening in Paris: Airbnb, Hotels, and The Parisian Market: A Case Study. Tourism Management, vol. 70, p. 78-88.

Ilieș A., Wendt, J. A. Ilieș, D.C., Herman, G.V., Ilieș M. \& Deac, A. L. (2016), The patrimony of wooden churches, built between 1531 and 2015, in the Land of Maramureș, Romania. Journal of Maps, Volume 12, 2016, pp 597-602 Issue sup1 (http://dx.doi.org/10.1080/17445647.2016.1243075).

Ilies A., Hurley P. D., Ilies D. C., \& Baias S. (2017). Tourist animation -a chance adding value to traditional heritage: case studys in the Land of Maramures (Romania). Revista de Etnografie şi Folclor, New Series 1-2.

Ivanova, M. (2013). Factors for the Internationalization of Hotel Chains. Izvestiya, vol. 1, p. 107-118

Ivanova, M., \& Ivanov, S. (2014). Hotel Chains' Entry Mode in Bulgaria. Anatolia - An International Journal of Tourism and Hospitality Research, vol. 25, no. 1, p. 131-135.

Ivanova, M., Ivanov, S., \& Magnini, V.P. (2016). The Routledge Handbook of Hotel Chain Management. London: Routledge.

Lee, K.H., Kang, S., Terry, W.C., \& Schuett, M.A. (2018). A Spatial Relationship Between the Distribution Patterns of Hotels and Amenities in the United States. Cogent Social Sciences. vol. 4, no. 1, 1444918.

Li, Y. Du, T. (2018). Assessing the Impact of Location on Hotel Development: An Analysis of Manhattan Hotels, 1822-2012. Papers in Applied Geography, vol. 4, no. 1, p. 21-33.

Lund, K.J. (2006). The Geographical Concentration of Hotels in Switzerland and the Industry Life Cycle. Tourism and Hospitality Planning \& Development, vol.3, no. 1, p. 1-18.

Luo, H., \& Yang, Y. (2013). Spatial Distribution of Hotels in China. Tourism and Hospitality Research, vol. 13, no. 1, p. 3-15.

Luo, H.,\& Yang, Y. (2016). Intra-Metropolitan Location Choice of Star-rated and Non-rated Budget Hotels: The Role of Agglomeration Economies. International Journal of Hospitality Management, vol. 59, p. $72-83$.

Magombo, A., Rogerson, C.M., \& Rogerson, J.M. (2017). Accommodation Services for Competitive Tourism in subSaharan Africa: Historical Evidence from Malawi. Bulletin of Geography: Socio-Economic Series, vol. 38,p.73-92.

McKelly, D., Rogerson, C.M., van Huysteen, E., Maritz, J., \& Ngidi, M. (2017). Spatial Trends in Tourism Within South Africa: The Expected and the Surprising. South African Journal of Geomatics, vol. 6, no. 2, p. 219-231.

Müller, D. (2016). On the Location of Tourism: An Outlook from Europe's Northern Periphery. In M. Mayer \& H. Job (eds.), Naturtourismus: Chancen und Herausforderungen, Mannheim: Meta GIS Systems, p. 113-124.

Müller, D. (2018). Time to Reconsider Tourism Geographies? Tourism Geographies, vol.20, no. 1, p. $172-174$.

Navratil, J., Svec, R., Picha, K., \& Dolezalova, H. (2012). The Location of Tourist Accommodation facilities: A Case Study of the Sumava Mtn. and South Bohemia Tourist Regions (Czech Republic). Moravian Geographical Reports, vol. 20, no. 3, p. 50-63.

Niewiadomski, P. (2014). Towards an Economic-geographical Approach to the Globalization of the Hotel Industry, Tourism Geographies, vol. 16, p. 48-67.

Niewiadomski, P. (2015). International Hotel Groups and Regional Development in Central and Eastern Europe. Tourism Geographies, vol. 17, no. 2, p. 173-191.

Niewiadomski, P. (2016). The Globalization of the Hotel Industry and the Variety of Emerging Capitalisms in Central and Eastern Europe. European Urban and Regional Studies, vol. 23, no. 3, p. 267-288.

Niñerola, A., Campa-Planas, F., Hernàndez-Lara, A., \& Sanchez-Rebull, M-V. (2016). The Experience of Melia Hotels International in China: A case of Internationalization of a Spanish Hotel Group. European Journal of Tourism Research, vol. 12, p. 191-196.

Pandy, W., \& Rogerson, C.M. (2013a). The Timeshare Industry of Africa: A Study in Tourism Geography. Bulletin of Geography: Socio-Economic Series, vol. 21, p. 97-109.

Pandy, W., \& Rogerson, C.M. (2013b). The Timeshare Industry of South Africa: Analysis and Contemporary Challenges. African Journal for Physical, Health Education, Recreation and Dance, vol. 19 (Supplement 2), p. 248-266.

Pandy, W., \& Rogerson, C.M. (2014a). The Evolution and Consolidation of the Timeshare Industry in a Developing Economy: The South African Experience. Urbani izziv, vol. 25 (Supplement), S162-S175. 
Pandy, W., \& Rogerson, C.M. (2014b). The Making of the South African Timeshare Industry: Spatial Structure and Development Challenges. Bulletin of Geography: Socio-Economic Series, 26, 183-201.

Pearce, D.G. (1979). Towards a Geography of Tourism. Annals of Tourism Research, vol. 7, p. 245-272.

Pearce, D.G. (1987). Spatial Patterns of Package Tourism in Europe. Annals of Tourism Research, vol. 14, no.2, p.183-201.

Pearce, D. G., \& Grimmeau, J.P. (1985). The Spatial Structure of Tourist Accommodation and Hotel Demand in Spain. Geoforum, vol. 16, no. 1, p. 37-50.

Polyzos, S., \& Minetos, D. (2011). An Ordinal Regression Analysis of Tourism Enterprises' Location Decisions in Greece. Anatolia: An International Journal of Tourism and Hospitality Research, vol. 22, no. 1, p. $102-119$.

Pons, A., Rullan, O., \& Murray, I. (2014). Tourism Capitalism and Island Urbanization: Tourist Accommodation Diffusion in the Balearics, 1936-2010. Island Studies Journal, vol. 9, no. 2, p. 239-258.

Puciato, D. (2016). Attractiveness of Municipalities in South-Western Poland as Determinants for Hotel Chain Investments. Tourism Management, vol. 57, p. 245-255.

Puciato, D., Gawlik, A., \& Goranczewski, B. (2017). Location Factors of Foreign and Domestic Investors in the Hospitality Industry of Poland. International Journal of Contemporary Management, vol. 15, no. 4, p. 31-55.

Rahovan, A-L. (2013). Transylvanian Hotels and Their Economic Impacts on Tourism. GeoJournal of Tourism and GeoSites, vol. 12, no. 2, p. 163-174.

Ritchie, J.R.B., \& Crouch, G.I. (2003). The Competitive Destination: A Sustainable Tourism Perspective. Wallingford: CABI.

Rogerson, C.M. (2014). The Uneven Geography of Tourism in South Africa. African Journal of Hospitality, Tourism and Leisure. vol. 3, no. 1, p. 1-15.

Rogerson, C.M. (2015a). Restructuring the Geography of Domestic Tourism in South Africa. Bulletin of Geography: Socio-Economic Series, vol. 29, p. 119-135.

Rogerson, C.M. (2015b). Revisiting VFR Tourism in South Africa. South African Geographical Journal, vol. 97, no. 2, p. 139-157.

Rogerson, C.M. (2015c). Tourism and Regional Development: The Case of South Africa's 'Distressed Areas'. Development Southern Africa, vol. 32, p. 277-291.

Rogerson, C.M. (2015d). The Uneven Geography of Business Tourism in South Africa. South African Geographical Journal, vol. 97, no. 2, p. 183-202.

Rogerson, C.M. (2016a). Secondary Cities and Tourism: The South African Record. African Journal of Hospitality, Tourism and Leisure. Vol. 5, no. 2, p. 1-12.

Rogerson, C.M. (2016b). Outside the Cities: Tourism Pathways in South Africa's Small Towns and Rural Areas. African Journal of Hospitality, Tourism and Leisure, vol. 5, no. 3, p. 1-16.

Rogerson, C.M. (2017a). The Economic Geography of South Africa's International Tourism Industry. Acta Universitatis Danubius Oeconomica, vol. 13, no. 2, p. 66-80.

Rogerson, C.M. (2017b). Less Visited Tourism Spaces in South Africa. African Journal of Hospitality, Tourism and Leisure, vol. 6, no. 3, p. 1-17.

Rogerson, C.M. (2017c). Unpacking Directions and Spatial Patterns of VFR Travel Mobilities in the Global South: Insights from South Africa. International Journal of Tourism Research, vol. 19, p. 466-475.

Rogerson, C.M. (2017d). Visiting Friends and Relatives Matters in sub-Saharan Africa. African Journal of Hospitality, Tourism and Leisure, vol. 6, no. 3, p. 1-10.

Rogerson, C.M. (2018). Informal Sector City Tourism: Cross-Border Shoppers in Johannesburg. GeoJournal of Tourism and GeoSites, vol. 22, p. 381-392.

Rogerson, C.M., \& Nel, E.L. (2016a). Redressing Inequality in South Africa: The Spatial Targeting of Distressed Areas. Local Economy, vol. 31, nos. 1-2, p. 28-41.

Rogerson, C.M., \& Rogerson, J.M. (2017). City Tourism in South Africa: Diversity and Change. Tourism Review International, vol. 21, no. 2, p. 193-211.

Rogerson, C. M, \& Rogerson, J.M. (2018). Africa's Tourism Economy: Uneven progress and Challenges. In T. Binns, K. Lunch and E. Nel. (eds). The Routledge Book of African Development. Abingdon: Routledge, p. 545-560.

Rogerson, C.M., \& Rogerson, J.M. (2019). Tourism and Accommodation Services in South African: A Spatial Perspective. In J. Knight and C.M Rogerson (eds), Geography of South Africa: Contemporary Changes and New Directions. Cham, Springer International, p. 213-220.

Rogerson, J.M. (2010). The boutique hotel industry in South Africa: Definition, scope and organization. Urban Forum, vol.21, p. 425-439.

Rogerson, J.M. (2011a). The limited services hotel in South Africa: The growth of City Lodge. Urban Forum, vol. 22,p.343-361.

Rogerson, J.M. (2011b). The changing all-suite hotel in South Africa: From 'extended stay' to African condo hotel. Tourism Review International, vol. 15, no. (1/2), p. 107-121.

Rogerson, J.M. (2012). The Changing Location of Hotels in South Africa's Coastal Cities, 1990-2010. Urban Forum, vol. 23, no. 1, p. 73-91.

Rogerson, J.M. (2013a). The economic geography of South Africa's hotel industry 1990 to 2010. Urban Forum, vol. 24, no. 3, p. 425-446.

Rogerson, J.M. (2013b). Reconfiguring South Africa's hotel industry 1990-2010: Structure, segmentation, and spatial transformation. Applied Geography, vol. 36, p. 59-68.

Rogerson, J.M. (2013c). Market Segmentation and The Changing Budget Hotel Industry of Urban South Africa. Urbani izziv, vol. 24, no. 2, p. 112-123. 
Rogerson, J.M. (2013d). Urban Tourism and the Changing Structure of the Hotel Economy in South Africa. African Journal for Physical, Health Education, Recreation and Dance, vol. 19 (Supplement 2), p. 39-54.

Rogerson, J.M. (2014a). Hotel Location in Africa's World Class City: The Case of Johannesburg, South Africa. Bulletin of Geography: Socio-Economic Series, vol. 25, p. 181-196.

Rogerson, J.M. (2014b). Changing Hotel Location Patterns in Ekurhuleni, South Africa's Industrial Workshop. Urbani izziv, vol. 25 (Supplement), p. S81-S95.

Rogerson, J.M. (2016). Hotel chains of the global South: The internationalization of South African hotel brands. Tourism - An International Interdisciplinary Journal, vol. 64, p. 445-450.

Rogerson, J.M., \& Rogerson, C.M. (2014). Maximising the Local Development Potential of Nature Tourism Accommodation Establishments in South Africa. African Journal of Hospitality, Tourism and Leisure, vol. 3 , no. 1, p. 1-20.

Saarinen, J. (2014). Tourism Geographies: Connections with Human Geography and Emerging Responsible Geographies. Geographia Polonica, vol. 87, p. 343-352.

Saarinen, J., Hall, C.M., \& Rogerson, C.M. (2017). Geographies of Tourism Development and Planning. Tourism Geographies, vol. 19, no. 3, p. 307-317.

Santos, M., Brochado, A., \& Esperanca, J. (2016). Foreign Direct Investment Patterns of Global Hotel Chains. Journal of Business Research, vol. 69, no. 11, p. 5235-5240.

Shen, Y., Morrison, A.M., Wu, B., Park, J., Li, C., \& Li, M. (2018). Where in the World?: A Geographic Analysis of a Decade of Research in Tourism, Hospitality, and Leisure Journals. Journal of Hospitality \& Tourism Research, vol. 42, no. 2, p. 171-200.

Shoval, N. (2006). The Geography of Hotels in Cities: An Empirical Validation of a Forgotten Model. Tourism Geographies, vol. 8, p. 56-75.

Shoval, N., \& Cohen-Hattab, K. (2001). Urban Hotel Development Patterns in the Face of Political Shifts. Annals of Tourism Research, vol. 28, p. 908-925.

Shoval, N. Kercher, B. Ng, E., \& Birenboim, A. (2011). Hotel Location and Tourist Activity in Cities. Annals of Tourism Research, vol. 38, p. 1594-1612.

Timothy, D. (2018). Geography: The Substance of Tourism. Tourism Geographies, vol.20, no. 1, p. 166-169.

Timothy, D., \&Teye, V. (2009). Tourism and the Lodging Sector. London: Butterworth-Heinemann.

Urtasun, A., \& Gutiérrez, I. (2006). Hotel Location in Tourism Cities: Madrid 1936-1998. Annals of Tourism Research, vol. 33, p. 382-402.

Visser, G. (2003). South African Tourism and its Role in the Perpetuation of an Uneven Space Economy. Africa Insight, vol. 33, no. 1/2, p. 116-123.

Visser, G. (2007). Geography of Tourism. In R. George (ed.). Managing Tourism in South Africa, Cape Town: Oxford University Press, p. 34-52.

Visser, G. (2016). South African Tourism Geographies: Progress and Prospects. South African Geographical Journal, vol. 98, no. 3, p. 428-438.

Visser, G., \& van Huyssteen, K. (1997). Guest Houses - New Options for Tourists in the Western Cape Winelands. Acta Academica, vol. 29, p. 106-133.

Visser, G., \& van Huyssteen, K. (1999). Guest Houses: The Emergence of a New Tourist Accommodation Type in the South African Tourism Industry. Tourism and Hospitality Research, vol. 1, p. 155-175.

Visser, G., Erasmus, I., \& Miller, M. (2017). Airbnb: The Emergence of a New Accommodation Type in Cape Town, South Africa. Tourism Review International, vol.21, no. 2, p. 151-168.

Walford, N. (2011). Patterns of Development in Tourist Accommodation Enterprises on Farms in England and Wales. Applied Geography, vol. 21, no. 4, p. 331-345.

Wang, D.G. (2008). Spatial Structure of Tourism Resources in the Tourism Region of Hulun Buir-Aershan. Arid Land Geography, vol. 31, no. 3, p. 456-463 (in Chinese).

Weaver, D., \& Elliott, K. (1996). Spatial Patterns and Problems in Contemporary Namibian Tourism. The Geographical Journal, vol 162, p. 205-217.

Wen, J.J., \& Sinha, C. (2009). The Spatial Distribution of Tourism in China: Trends and Impacts. Asia Pacific Journal of Tourism Research, vol. 14,no. 1, p. 93-104.

Williams, S. (2009). Tourism Geography: A New Synthesis. Abingdon: Routledge.

Yang, Y., \& Wong, K.K.F. (2013). Spatial Distribution of Tourist Flows in China's Cities. Tourism Geographies, vol. 15, no. 2, p. 338-363.

Yang, Y., Luo, H., \& Law, R. (2014). Theoretical, Empirical and Operational Models in Hotel Location Research. International Journal of Hospitality Management, vol. 36, p. 209-220.

Yang, Y., Wong, K.K.F., \& Wang, T. (2012). How do Hotels Choose their Location?: Evidence from Hotels in Beijing. International Journal of Hospitality Management, vol. 31, p. 675-685.

*** South African Tourism (2016). 2015 Annual Report. Johannesburg: South African Tourism.

*** Statistics South Africa (2015). Domestic Tourism Survey 2015. Pretoria: Stats SA.

Submitted:

06.10.2018
Revised:

21.11.2018
Accepted and published online 23.11.2018 